\author{
Teresa Jaroszuk \\ Uniwersytet Warmińsko-Mazurski \\ w Olsztynie
}

\title{
Teoria wykształcenia w myśli pedagogicznej Bogdana Nawroczyńskiego
}

Wykształcenie (w ujęciu Bogdana Nawroczyńskiego przejaw życia duchowego) odgrywało szczególną rolę w jego myśli pedagogicznej. Charakter i znaczenie wykształcenia omówił szeroko w swej znakomitej książce Zasady nauczania ${ }^{1}$. Zagadnienie wykształcenia rozważał tam w konwencji psychologii strukturalnej i dlatego nazwał je układem spoistym skupionym wokół pewnych wartości ${ }^{2}$. Obok wykształcenia, do układów spoistych, szczególnie ważnych dla pedagoga, Nawroczyński zaliczył charakter i osobowość człowieka.

Wykształceniem nazywał pewien wytwór (rezultat) czynności nauczania. Przez pojęcie ,wykształcenie” rozumiał także ideał wykształcenia, którego urzeczywistnieniem ma być właśnie ów wytwór nauczania ${ }^{3}$. Kształcić człowieka może - uważał Nawroczyński - zarówno nauczanie, jak i wychowanie. Nawiązywał w ten sposób do poglądów G. Kerschensteinera wyłożonych w książce Theorie des Bildung (1926). Nawroczyński był zdania, że i wychowanie, i nauczanie mają swój udział w wykształceniu, gdyż opierać się może ono na dobrach moralnych (wychowanie) i na dobrach poznawczych (nauczanie). Tylko z pozoru - twierdził - wychowanie kształci jedynie wolę i uczucia, a nauczanie tylko inteligencję. Tego rodzaju zróżnicowanie jest - zdaniem autora - niesłuszne, gdyż między wychowaniem i nauczaniem istnieje pewien związek, mają bowiem wspólny cel rozwijanie całego człowieka, a nie tylko poszczególnych jego dyspozycji ${ }^{4}$.

$\mathrm{Z}$ tego powodu możliwa jest - utrzymywał - teoria wykształcenia, niejako krzyżująca się z teorią wychowania i teorią nauczania. Przyjmował ją jako teorię

${ }^{1}$ B. Nawroczyński, Zasady nauczania, 1 wyd., Lwów-Warszawa 1930; 2 wyd. 1931; 3 wyd. 1935; 4 wyd., Wrocław 1946; 5 wyd. 1948. W książce tej doprecyzował swoje poglądy na temat wykształcenia, ogłoszone poprzednio w rozprawie: Kształcenie $i$ wyksztatcenie, „Muzeum” 1928. Cytaty według wyd. 3 .

${ }^{2}$ B. Nawroczyński, Zasady nauczania ..., s. 90.

${ }^{3}$ Tamże, s. 10.

${ }^{4}$ Tamże, s. 14. 
mającą wiele zalet badawczych ${ }^{5}$. W takim postawieniu sprawy przejawia się tak częsta u Nawroczyńskiego dążność do precyzji terminologicznej i maksymalnego uściślania poglądów obcych pedagogów. O tym pisał zresztą w przedmowie do pierwszego wydania książki Zasady nauczania:

do podjęcia tej pracy skłoniła mię przede wszystkim chęć wydobycia siebie i innych z tego ciemnego gąszczu niejasnych, nieścisłych [...] często w dodatku niezgodnych ze sobą poglądów na nauczanie, w jakim obecnie żyjemy.

Pogłębione rozważania Nawroczyńskiego o wykształceniu znajdujemy w kolejnych rozdziałach wspomnianej książki .

Ważne są szczególnie jego uwagi o wykształceniu rozumianym jako ideał pedagogiczny kierujący czynnością kształcenia. Ten ideał jest tylko zadaniem, celem, którego nigdy nie da się osiągnąć. Realizuje się (tylko częściowo) w wytworach kształcenia, ale rezultaty są jedynie przybliżeniem do ideału, nigdy nim samym. Dlatego wykształcenie (wytwór) - pouczał Nawroczyński - nie jest tym samym, co ideał wychowawczy.

Z krótkiego przeglądu epok historycznych, w których uświadamiano sobie wykształcenie jako ideał pedagogiczny, Nawroczyński wyprowadza wniosek, że wykształcenie nie jest tylko ćwiczeniem umysłu, ani nie jest powierzchowną erudycją. Musi natomiast mieć ono podłoże intelektualności, musi być zespolone w całość z osobowością człowieka wykształconego i nacechowane jego indywidualnością. Z tego powodu Nawroczyński krytykuje potoczny zwrot „ktoś ma wykształcenie”. Tutaj przecież „ma” w tym sensie jak się ma rzecz, którą można nabyć, można się jej pozbyć, sprzedać, można ją zgubić. Nie można również wykształcenia „mieć” w taki sposób, jak się ma w pamięci jakieś szczegóły i informacje, które szybko i bezpowrotnie z pamięci znikają. Pisał:

Natomiast można i należy być człowiekiem wykształconym. Pierwszym po temu warunkiem jest tak głębokie przyswojenie tych dóbr duchowych, które składają się na kulturę duchową własnego narodu i ludzkości, takie ich przetrawienie, aby one przestały być dla kształcącej się jednostki obcymi dobrami, lecz stały się jej wewnętrznym życiem duchowym, sferą jej ideałów życiowych, rozpędem sił twórczych, jednym słowem nią samą ${ }^{7}$.

Podsumowując niejako sentencję zawartą w tym cytacie Nawroczyński pisze, że wykształcenie to jakby zespolenie „dwóch światów”. Jeden ,świat” to cenne wytwory ducha ludzkiego, kultura duchowa określonego społeczeństwa w danej epoce: język, obyczaje, moralność, wierzenia religijne, formy życia społecznego, arcydzieła poezji, muzyki, sztuk plastycznych, utwory filozoficzne i naukowe,

\footnotetext{
${ }^{5}$ Tamże, s. $14-15$.

${ }^{6}$ Tamże, s. $106-110$.

${ }^{7}$ Tamże, s. 108.
} 
szeroka dziedzina techniki. Wszystkie te wytwory poszczególnych okresów rozwoju danego społeczeństwa stanowią całość mającą swój własny styl. Tę właśnie całość Nawroczyński nazywa kulturą duchową danego społeczeństwa.

Drugi „świat” składający się na wykształcenie to wewnętrzne życie duchowe człowieka - jednostki. Całość obu ma być dopiero „prawdziwym wykształceniem”, ideałem wykształcenia według Nawroczyńskiego. Ideał zatem to najściślejsze i harmonijne zespolenie indywidualności człowieka z głęboko przyswojoną przez niego kulturą. Nie może tu zachodzić sprzeczność, czyli człowiek musi akceptować poznane przez niego zasady i wartości kultury.

Ideał wykształcenia Nawroczyński rozumie jako ideał pedagogiczny. Ma się on bowiem urzeczywistniać w żywym, rozwijającym się człowieku dzięki jego własnym wysiłkom i uświadomionym pragnieniom. Zadaniem nauczyciela jest wspomagać proces narastania wykształcenia, stwarzać dogodne warunki, aby ten proces zaistniał, a gdy już będzie, to nim kierować. Rozważania o ideale wykształcenia Nawroczyński kończy powtórnie przywołanym stwierdzeniem: „Ideał tylko wskazuje kierunek doskonalenia się, sam jest zadaniem i stawia zadania, ale nigdy nie będzie spełniony do końca".

Uzupełnieniem tych uwag są opinie dotyczące stopni i zakresu wykształcenia $^{8}$. Ideał jest jeden - podkreślał - ale jego urzeczywistnienia bardzo różne. Wielka bowiem jest rozmaitość indywidualności ludzkich, ogromna różnorodność społeczności i ożywiających je kultur. Tak było w przeszłości, tak było i w czasach Nawroczyńskiego. Każdy rolnik, robotnik, nauczyciel, inżynier, prawnik, lekarz, itd. jest człowiekiem zasługującym na miano człowieka ukształtowanego (to jest posiadającego swoją strukturę duchową) i wykształconego, o ile przyswoił sobie głęboko kulturę swego środowiska życiowego i zawodu, o ile kulturę tę podtrzymuje swą pracą i posuwa naprzód swą inicjatywą. Ukształtowanie jest możliwe w każdym zakresie kultury. I tu cytował Nawroczyński słynną w Polsce lat 20. XX w. autobiografię Henry'ego Forda, twórcy amerykańskiego przemysłu samochodowego, gdzie padało stwierdzenie, że „kto jest mistrzem w swoim zakresie", bez względu na to czym jest ten zakres, ten zdobył swój stopień akademicki i wkroczył w „królestwo mądrości”. I od siebie Nawroczyński stwierdzał, że o wykształceniu stanowi nie tyle ilość przyswojonych dóbr kulturalnych, ile stopień ich przyswojenia, przetworzenia na własną strukturę duchową i wyrażenia w działalności życiowej.

Nawroczyński przyznawał, że od zakresu przyswojonej kultury zależy rozległość wykształcenia. I dlatego potocznie uważa się za wykształconych tych, którzy dzięki studiom szkolnym, podróżom, itp. rozszerzyli swe horyzonty umysłowe. Nie wiadomo jednak, czy we wszystkich tych ludziach uformowała się struktura duchowa odpowiadająca nabytym wiadomościom.

${ }^{8}$ Tamże, s. $113-131$ 


\section{O B. Nawroczyńskim opublikowałam:}

Jaroszuk T., Z iskra filarecka w oku. Świat i dzieło Bogdana Nawroczyńskiego, Olsztyn 2004.

Jaroszuk T., Bogdana Nawroczyńskiego życie duchowe i nastawienie do okupacyjnej rzeczywistości, „Przegląd Historyczno-Oświatowy” 2007, t. 50, nr 1-2.

Jaroszuk T., Bogdana Nawroczyńskiego koncepcja szkoty/ refleksje z lektury książki Uczeń i klasa, [w:] Kreowanie tożsamości szkoły, t. 1, Konteksty teoretyczne, poglądy, wyniki badań, red.

K. Chałas, Lublin 2009. 